\title{
Seroprevalence estimate and associated risk factors for neosporosis in dairy cattle in the northwest region of Rio Grande do Sul State, Brazil
}

\author{
Patrícia Carvalho Gindri ${ }^{1} \odot$ Bruna $^{\circ i o n}{ }^{1} \odot$ Jorgea $^{\circ r a d i e e ́}{ }^{1}$ \\ Tatiane Senna Bialves ${ }^{2}$ Guilherme Nunes de Souza $^{3} \odot$ Odir Antônio Dellagostin ${ }^{4}$ \\ Augusto Schneider ${ }^{4}$ Lígia Margareth Cantarelli Pegoraro ${ }^{5^{*}}$ (?)
}

\footnotetext{
${ }^{1}$ Programa de Pós-graduação em Veterinária (PPGV), Universidade Federal de Pelotas (UFPel), Pelotas, RS, Brasil.

${ }^{2}$ Programa de Pós-graduação em Biologia Animal (PPGBA), Universidade Federal de Pelotas (UFPel), Pelotas, RS, Brasil.

${ }^{3}$ Empresa Brasileira de Pesquisa Agropecuária (EMBRAPA), Gado de Leite, Juiz de Fora, MG, Brasil.

${ }^{4}$ Universidade Federal de Pelotas (UFPel), Pelotas, RS, Brasil.

${ }^{5}$ Empresa Brasileira de Pesquisa Agropecuária (EMBRAPA), Clima Temperado, BR 392, Km 78, 96001-970, Pelotas, RS, Brasil.

E-mail: ligia.pegoraro@embrapa.br. "Corresponding author.
}

\begin{abstract}
The aim of this study was to estimate neosporosis seroprevalence and its associated risk factors in milk herds (Bos taurus taurus) located in the northwestern region of Rio Grande do Sul State, Brazil. Three hundred twenty-two blood samples were collected from dairy cows on 18 farms in 17 cities of this region. An epidemiologic questionnaire was completed for each farm. It consisted of questions about the general characteristics of the herd, reproduction, and animal management. Serum samples were tested for Neospora caninum using a commercial enzyme-linked immunosorbent assay (ELISA) kit. Results indicated a seroprevalence of Neospora in 88.9\% (16/18) of herds and $31.1 \%$ (100/322) of individuals. Risk factor analyses demonstrated that culling by reproductive disorder $(O R=0.6)$, flooding $(O R=0.5)$, and commercial sale $(O R=0.4)$ were associated with seroprevalence. Nevertheless, the purchase of replacement animals in the herd played an important role in disease occurrence $(O R=2.2)$. Results of this study suggested that Neospora caninum was present in the studied herds under investigation and that there are risk factors associated with its seroprevalence on the farms of the northwestern of Rio Grande do Sul. Key words: cattle, Neospora caninum, reproductive diseases.
\end{abstract}

Estimativa da soroprevalência e fatores de risco para neosporose em rebanhos leiteiros na região Noroeste do estado do Rio Grande do Sul, Brasil

RESUMO: O objetivo desse estudo foi estimar a soroprevalência da neosporose e os possíveis fatores de risco em rebanhos (Bos taurus taurus) localizados na mesorregião Noroeste do Rio Grande do Sul, Brasil. Foram coletadas 322 amostras de sangue de bovinos leiteiros, em 18 propriedades localizadas em 17 munícipios desta mesorregião. Um questionário epidemiológico foi aplicado em cada propriedade, contendo questões relacionadas às características gerais dos rebanhos, dados reprodutivos e manejo animal. As amostras de soro foram testadas através do teste de imunoensaio enzimático (ELISA) para Neospora caninum. Os resultados demonstraram uma soroprevalência de Neospora de 88,9\% (16/18) entre os rebanhos e 31,1\% (100/322) entre os individuos. Entre os fatores de risco analisados foi observado que descarte por problemas reprodutivos $(O R=0,6)$, presença de áreas alagadiças $(O R=0,5)$ e venda comercial $(O R=0,4)$ estavam associados a soroprevalência. No entanto, a compra de animais substituidos no rebanho desempenhou um papel significativo na ocorrência da doença $(O R=2,2)$. Os resultados desse estudo sugerem que o Neospora caninum esteve presente nos rebanhos estudados, bem como, existem fatores associados com a soroprevalência nas propriedades da mesorregião do Noroeste do Rio Grande do Sul.

Palavras-chave: bovinos, Neospora Caninum, doenças reprodutivas.

\section{INTRODUCTION}

Neosporosis is an economically important parasitic disease. It is correlated with reproductive losses, embryonic death and abortion in the first- and second trimesters of pregnancy (DUBEY, 2003). The etiologic agent is Neospora caninum, an intracellular protozoan of Phylum Apicomplexa (DUBEY, 1999). This parasite was originally mistaken for Toxoplasma gondii. However, DUBEY et al. (1988) identified it as new genus and species.

The definitive hosts of $N$. caninum are canids, including domestic dog (Canis familiaris), coyotes (Canis latrans), dingoes (Canis lupus dingo) 
and gray wolves (Canis lupus). These species excrete N.caninum oocysts (GONDIM et al., 2004; DUBEY et al., 2011). Cattle, sheep, horses, and buffaloes are intermediate hosts and harbor the cysts in their tissues (DUBEY \& SCHARES, 2011). They are infected through contact with farm implements, water, and food contaminated with seropositive canid feces (DUBEY et al., 2007). The parasite is transmitted across the herd both vertically and horizontally (GONDIM et al., 2004). Vertical transmission is the most important in terms of disease maintenance (NASCIMENTO et al., 2014), since it is intergenerational (DUBEY et al., 2007).

The main economic losses incurred by neosporosis infestations are related to the costs of aborted fetuses, decreases in cow productivity, delays in conception, reductions in milk production, and elevated veterinary, diagnostic, and therapeutic expenses (HADDAD et al., 2005; REICHEL et al., 2013). Neosporosis has been reported in all Brazilian states and has caused substantial losses for the cattle producers there (CÉZAR-CERQUEIRA et al., 2017). $N$. caninum has been identified in all cattle herds worldwide. Nevertheless, its seroprevalence varies among countries, regions within the same country, and production systems (DUBEY et al., 2007).

In southern states such as Paraná and Santa Catarina, the prevalence of Neospora caninum was 30.3-30.6\% (NASCIMENTO et al., 2014; FÁVERO et al., 2017). In Rio Grande do Sul, this disease poses both sanitary and economic threats (VOGEL et al., 2006). Its prevalence ranges from $17-60 \%$ (COBERLLINI et al., 2006; FRANDOLOSO et al., 2008). One study reported a higher prevalence of neosporosis in dairy cattle than beef (RAGOZO et al., 2003) possibly because cows are in close proximity with dogs and stress of daily management is relatively high (MOORE, 2005). The main risk factors associated with neosporosis on dairy farms are existing reproductive dysfunction, senescent animals,presence of dogs and their proximity to herd, climatic conditions conducive to oocyst formation, introduction of undiagnosed animals, and improper biosecurity practices (GUIMARAES JÚNIOR et al., 2004; CORBELLINI et al., 2006; DUBEY et al., 2007; FÁVERO et al., 2017).

Northwestern Rio Grande do Sul is the main milk-producing area in the state. Its yield is 3,093,412L annually (IBGE, 2017). Therefore, any decreases in reproductive efficiency result in substantial economic losses in this sector. Therefore, studies of the causes of reproductive diseases and the losses resulting from them are warranted. It is also necessary to investigate the risk factors associated with the transmission and prevalence of neosporosis in this region. The aim of this study, then, was to estimate neosporosis seroprevalence and infection risk in the herds of northwestern Rio Grande do Sul.

\section{MATERIALS AND METHODS}

The study was conducted between July and October 2016. It involved 322 serum samples obtained from dairy cattle $>24$ mo old on 18 different farms. All of the ranches were affiliated with a farmer association and were distributed across 17 cities in northwestern Rio Grande do Sul. These included Braga, Bom Progresso, Bozano, Catuípe, Derrubadas, Esperança do Sul, Fortaleza dos Valos, Ijuí, Joia, Miraguaí, Panambi, Salto do Jacuí, Santo Augusto, Sede Nova and Três Passos.

\section{Sampling}

An effective sample size was estimated according to the method PETRIE \& WATSON (2009). It was determined by EpiTools ${ }^{\circledR}$ software (AusVet Animal Health Services and Australian Biosecurity Cooperative Research Centre for Emerging Infectious Disease; SERGEANT, 2014). For individual cows, the input parameters used were (a) an expected prevalence of $15 \%$, (b) a sampling loss of $5 \%$, and (c) significance level of $95 \%$. For herds, the input parameters were (a) an expected seroprevalence of $30 \%$, (b) a sampling loss of $20 \%$, and (c) significance level of $95 \%$. The estimated total number of animals was divided by the number of herds available for sampling $(n=18)$ to calculate the number of animals sampled per herd. It was determined that 8.8 animals herd ${ }^{-1}$ were needed for effective sampling. In practice; however, the sampling was higher $(\mathrm{n}=322)$ because other manipulations were performed on the data to ensure adequate statistical power.

\section{Epidemiological questionnaire}

The methodology of this study consisted of collecting serum samples and gathering information about the conditions of each farm by completing epidemiological questionnaire (Table 1).

\section{Samples collection and serologic diagnostic}

Serum samples were collected by jugular or coccygeal venipuncture. The needle $(25 \mathrm{~mm} \mathrm{x}$ $0.8 \mathrm{~mm}(21 \mathrm{G})$ ) was connected to a vacuum system and transferred $10 \mathrm{~mL}$ of blood to each sterile anticoagulant-free test tube. Samples were identified according to the information declared on the individual epidemiological questionnaires. 
Table 1 - Overview of the epidemiological questionnaire used on the dairy farms of northwestern Rio Grande do Sul.

\begin{tabular}{lc}
\hline Characteristic & Variables \\
Farm & $\begin{array}{c}\text { Production system (confinement, semi-confinement, extensive, semi-intensive); technical assistance (veterinarian, } \\
\text { agronomist); breed (Holstein, Jersey, crossbreed), feed (silage, concentrate, pasture) number, age, animal categories } \\
\text { (calves, heifers, milking cows, dry cows) area (in ha) }\end{array}$ \\
$\begin{array}{l}\text { Reproductive } \\
\text { performance }\end{array}$ & $\begin{array}{r}\text { Reproduction technique (natural breeding (NB), artificial insemination (AI), NB+AI), reproductive disorders (repeat } \\
\text { breeding, abortion, calving interval, diagnoses of reproductive diseases (IBR, BVD, leptospirosis, neosporosis, } \\
\text { brucellosis), calving abnormalities, in/adequate calving area }\end{array}$ \\
Biosecurity & $\begin{array}{r}\text { Presence of other animals (sheep, goats, swine, horses, rats, dogs), flooding, culling (reproductive failures, age, low } \\
\text { production, animal purchase), cow replacement (own herd or purchase), sale, sanitary management }\end{array}$ \\
\hline
\end{tabular}

Samples were then packed in insulated boxes $4^{\circ} \mathrm{C}$ and sent to a laboratory. They were centrifuged at $214 \mathrm{G}$ for $20 \mathrm{~min}$ to separate and isolate the sera. Duplicate two-milliliter serum aliquots were transferred to cryotubes and stored at $-20^{\circ} \mathrm{C}$. Anti-Neospora caninum antibodies were detected in bovine serum by enzyme-linked immunosorbent assay (ELISA) performed with IDEXX ${ }^{\circledR}$ kit (IDEXX Laboratories, Inc., Westbrook, ME, USA). Its sensitivity was $100 \%$ and its specificity was $98.9 \%$. Samples were diluted 1:100 for the antibody count, according to manufacturer recommendations.

Results were scored either as positive (presence of anti-Neospora caninum antibodies) or negative (absence of anti-Neospora caninum antibodies) based on the ratio of the sample to positive control $(\mathrm{S} / \mathrm{P})$. Absorbance was measured with Biochrom ${ }^{\circledR}$ spectrophotometer (Biochrom Ltd. Cambridge, UK) at $\lambda=620-650 \mathrm{~nm}$. Samples were scored as seronegative when $\mathrm{S} / \mathrm{P}<0.5$ and seropositive when $\mathrm{S} / \mathrm{P}>0.5$.

\section{Statistical analysis \\ Prevalence}

Prevalence among individuals and herds was estimated from the ratio of the total number of animals and herds tested to the number of animals and herds empirically determined to be seropositive. The 95\% confidence interval (CI) of the seroprevalence among individuals was estimated according to the following formula:

ICP 95\% $=\mathrm{P} \pm 1,96 x \sqrt{[P x(1-P)] / n}$

where $P$ is the prevalence and $n$ is the number of individuals sampled (SAMPAIO, 1998). Prevalence among herds was estimated on the basis of $10 \%$ of the seropositive animals per herd within the study area.

\section{Risk factors}

Animals were classified either as positive or negative based on the results of their serological neosporosis diagnostic test. This classification was treated as the dependent- or response variable. Quantitative data of the characteristics of the herds, individual animals, and herd management obtained from the epidemiological questionnaires were categorized according to the descriptive statistics. The measurable data obtained from the questionnaires were treated as independent- or explanatory variable. $\mathrm{A} \chi^{2}$ test was used to evaluate the association between the response- and explanatory variables (univariate analysis).

A logistic regression model was used to estimate the risk for neosporosis. It was constructed according to the method of FRANKENA \& GRAAT (1997). Univariate analyses were run to identify any associations between each independent variable and the dependent variable. Risk factors were selected on the basis of independent variables providing coherent biological explanations for the occurrence of neosporosis. In addition, $P<0.20$ for these associations according to the $\chi^{2}$ test. After the candidate independent variables were selected, logistic regression models were applied. The dependent (response) variable was the serological neosporosis diagnosis and the independent (explanatory) variables were those selected by univariate analysis. Once the final logistic regression model was chosen, the coefficients (odds ratios; OR) were calculated. The relative risk of each independent variable was estimated in order to approximate the overall or total degree of risk. Statistical analyses were performed with SPSS v. 8.0 (IBM Corp., Armonk, NY, USA).

\section{RESULTS AND DISCUSSION}

ELISA determined that the seroprevalence of neosporosis was $88.9 \%(16 / 18)$ in the herds and $31.1 \%(100 / 322)$ in the individuals. Results indicated most of the herds had $\geq 1$ individual animal seropositive for Neospora caninum. A study 
conducted in southern- and northwestern Rio Grande do Sul determined via immunofluorescence antibody assay that $93.3 \%$ of the herds there had anti-Neospora antibodies (COBERLLINI et al., 2006). This finding corroborated our results. We found that $31.1 \%$ of the individual animals had $N$. caninum antibodies. Therefore, the protozoa were widely distributed in the dairy herds studied. However, immunofluorescence antibody assays run by CAMILLO et al. (2011) and KLAUCK et al. (2016) revealed $53.4 \%$ and $43.8 \%$ seroprevalence in the lactating dairy cows of central Rio Grande do Sul and western Santa Catarina, respectively. In contrast, COBERLINNI et al. (2006) reported only 16.2\% (129/724) individual seroprevalence in the same region as that of our study. Although, COBERLINNI et al. (2006) reported a similar herd prevalence to ours $(88.9 \%)$, there was a significant increase in individual animal seroprevalence within the studied region over the last decade. Reasons for this increase include improved investigative rigor of the etiology of reproductive diseases and declining efficiency of the measures taken to prevent and control $N$. caninum.

The epidemiological questionnaire considered variables associated with $N$. caninum seropositivity. The mean number of animals on the farms in the study area was $58.11 \pm 14.25$. Of these, $29.39 \pm 5.28$ were lactating. The mean area explored on each farm was $30.06 \pm 12.27$ ha. All dairy farms were similar in terms of general hygiene practices and technology. No significant differences were observed among production systems, reproductive management systems, breed, age, or calving number $(P>0.20)$ as they relate to seroprevalence. Production systems were either confined $(11.1 \% ; 2 / 18)$ or semi-confined $(88.9 \% ; 16 / 18)$. Production system was not regarded as a risk factor in the study performed by OGAWA et al. (2005). Most farms $(66.7 \% ; 12 / 18)$ practiced artificial insemination (AI) while the others used both AI and natural breeding. Studies in Southern Brazil reported relatively higher Neospora prevalences on farms using natural breeding (MARTINS et al., 2012). Breeds assessed in these trials were Holstein $(38.9 \% ; 7 / 18)$ and Jersey $(27.8 \% ; 5 / 18)$. However, both breeds were present on $33.3 \%(6 / 18)$ of farms. In the present study, we reported no correlation between breed and seroprevalence. Nevertheless, previous studies demonstrated that seroprevalence was higher in Holsteins than Zebus or Holstein $\times$ Zebu cows (GUIMARÃES JÚNIOR et al., 2004). The mean age was $5.15 \pm 0.13 \mathrm{y}$ and the animals had $2.89 \pm 0.1$ calvings. Previous studies demonstrated that in Brazil, cows $\leq 24$ mo were $3 \times$ as likely to be seropositive for
Neospora caninum as other age groups. Therefore, animal age could be a risk factor for this disease (GUIMARÃES JÚNIOR et al., 2004). According to COBERLLINI et al. (2006), seropositivity did not significantly differ among various animal age groups. Therefore, vertical transmission may be the major means of disease dispersal among the herds of Southern Brazil.

Seroprevalence did not significantly differ among the parameters related to reproductive performance (repeat breeders, abortion, clean calving area, artificial insemination) used in this study $(P>0.05)$. The pathogen cycle of neosporosis is associated with characteristic clinical reproductive signals. After ingestion, the parasite crosses the intestinal wall, reaches the blood or lymph, and multiplies by producing various cell types (DUBEY et al., 2007). Cysts impede nutrient transport to the fetus (ALMÉRIA, 2009) and impair its development. Cysts can also suppress host immunity and rupture during pregnancy, thereby infecting the placenta or fetus and cause stillbirth or abortion (FARIAS, 2016). Several studies identified relatively higher prevalences of Neospora in animals with reproductive disorders (ALMÉRIA et al., 2009; MARTINEZ et al., 2017; KLAUCK et al., 2016; FÁVERO et al., 2017). In our study and that of MOURA et al. (2012); however, no significant association between these two factors was detected. Conversely our results demonstrated that culling by reproductive disorders was correlated with a relatively higher seroprevalence of $N$. caninum antibodies $(\mathrm{OR}=0.6)$ (Table 2$)$. Although, no animals presented with clinical symptoms of neosporosis during sampling, reproductive disorders were nonetheless criteria for animal culling. Seropositivity and abortion risk associated with $N$. caninum infection may stabilize over time (PABÓN et al., 2007). After epidemic abortion occurs, endemic abortion may follow (ANDERSON et al., 2000).

Studies have reported that abortion epidemics may be correlated with the ingestion of food or water contaminated with oocysts (DUBEY \& SCHARES, 2006). Moreover, flooding may also be a risk factor because it can spread $N$. caninum oocysts (JUSTO et al., 2013). Contrary to JUSTO et al. (2013), our results showed that flooding was actually associated with a lower $N$. caninum seroprevalence $(\mathrm{OR}=0.5)$. One possible explanation is that the presence of flooded area limits the access of the definitive hosts (canids), which are the main vectors of oocysts for bovines (DUBEY, 2003).

Of all variables studied, the main risk factor correlated with seropositivity was 
Table 2 - Frequency distribution of neosporosis seroprevalence in individuals according to the biosecurity variables listed in the epidemiological questionnaire used in northwestern Rio Grande do Sul.

\begin{tabular}{|c|c|c|c|c|c|c|c|}
\hline \multirow[t]{2}{*}{ Variable } & \multirow[t]{2}{*}{ Description } & \multicolumn{2}{|c|}{---------Negative--------- } & \multicolumn{2}{|c|}{--------Positive-------- } & \multirow[t]{2}{*}{$\mathrm{P}$} & \multirow[t]{2}{*}{ OR } \\
\hline & & $\mathrm{N}$ & $\%$ & $\mathrm{~N}$ & $\%$ & & \\
\hline \multirow[t]{2}{*}{ Presence of other animals } & Yes & 204 & 68.5 & 94 & $31.5^{\mathrm{a}}$ & 0.505 & 1.4 \\
\hline & No & 18 & 75.0 & 6 & $25.0^{\mathrm{a}}$ & & \\
\hline \multirow[t]{2}{*}{ Flooding } & Yes & 140 & 74.9 & 47 & $25.1^{\mathrm{a}}$ & 0.007 & 0.5 \\
\hline & No & 82 & 60.7 & 53 & $39.3^{\mathrm{b}}$ & & \\
\hline \multirow[t]{2}{*}{ Flooded area access } & Yes & 55 & 67.1 & 27 & $32.9^{\mathrm{a}}$ & 0.671 & 1.1 \\
\hline & No & 167 & 69.6 & 73 & $30.4^{\mathrm{a}}$ & & \\
\hline \multirow[t]{2}{*}{ Purchase of animals } & Own herd & 126 & 77.8 & 36 & $22.2^{\mathrm{a}}$ & 0.001 & 2.2 \\
\hline & Both & 96 & 60.0 & 64 & $40.0^{\mathrm{b}}$ & & \\
\hline \multirow[t]{2}{*}{ Commercial sale } & Yes & 166 & 65.1 & 89 & $34.9^{\mathrm{a}}$ & 0.004 & 0.4 \\
\hline & No & 56 & 83.6 & 11 & $16.4^{\mathrm{b}}$ & & \\
\hline \multirow[t]{2}{*}{ Culling by age } & Yes & 29 & 76.3 & 9 & $23.7^{\mathrm{a}}$ & 0.296 & 1.5 \\
\hline & No & 193 & 68.0 & 91 & $32.0^{\mathrm{a}}$ & & \\
\hline \multirow[t]{2}{*}{ Culling by reproductive disorders } & Yes & 71 & 61.2 & 45 & $38.8^{\mathrm{a}}$ & 0.024 & 0.6 \\
\hline & No & 151 & 73.3 & 55 & $26.7^{\mathrm{b}}$ & & \\
\hline \multirow[t]{2}{*}{ Culling by disease } & Yes & 127 & 65.5 & 67 & $34.5^{\mathrm{a}}$ & 0.097 & 0.7 \\
\hline & No & 95 & 74.2 & 33 & $25.8^{\mathrm{a}}$ & & \\
\hline
\end{tabular}

the purchase of replacement animals $(\mathrm{OR}=2.2)$ (Table 2). Commercial animal sale and replacement were significantly correlated with $N$. caninum seroprevalence $(\mathrm{OR}=0.4)$ (Table 2). Risks of introducing and spreading neosporosis were relatively high on farms not performing serological tests on animals prior to their purchase (BECK et al., 2010). Studies have shown relatively higher seropositivity rates on farms that purchase replacement animals since infection can be introduced by acquiring seropositive animals that were not pretested (ASMARE et al., 2013; FÁVERO et al., 2017). A strongly indicated preventive measure is the performance of sanitary tests before purchasing animals and introducing them into the herd. Seropositive animals obtained from other farms can vertically transmit the pathogen and compromise the reproductive efficiency of the herd (DUBEY et al., 2007). In northwestern Rio Grande do Sul, neosporosis is disseminated and maintained on farms primarily by vertical pathogen transmission (HEIN et al., 2012). Control strategies should be adopted to eliminate seropositive animals from herds, to accept only seronegative replacement animals, to dispose abortuses correctly, and to prevent canids from ingesting raw viscera. In this way, disease transmission and economic losses are mitigated (HEIN et al., 2012).

\section{CONCLUSION}

Neospora caninum was repoted in $88.9 \%$ of the herds and $31.1 \%$ of the individual cows studied in northwestern Rio Grande do Sul. In this region, the purchase of replacement animals was an important risk factor and was found to be highly correlated with neosporosis infection. We suggested that control measures be implemented that address the major regional neosporosis transmission risk factors and reduce the seroprevalence of Neospora caninum antibodies in both herds and individual animals.

\section{ACKNOWLEDGMENTS}

We thank to EMBRAPA (project number 02.13.06.016.00.00) for the financial support, Coordenação de Aperfeiçoamento de Pessoal de Nível Superior (CAPES) (Patrícia Carvalho Gindri, Bruna Mion), Conselho Nacional de Desenvolvimento Científico e Tecnológico (CNPq) (Jorgea Pradieé), Rede Leite, Emater Regional Ijuí, Universidade Regional do Noroeste do Estado do Rio Grande do Sul-Unijuí, and Universidade Federal de Pelotas (UFPel) for their technical financial support.

\section{BIOETHICS AND BIOSSECURITY COMMITTEE APPROVAL}

The committee on ethics and biosafety approved this study and considered its methodology to be compatible with the Ethical Principles in Animal Experimentation (23110.007027/2015-76). 


\section{DECLARATION OF CONFLICTING INTERESTS}

The authors declared no potential conflicts of interest with respect to the research, authorship, and/or publication of this article.

\section{REFERENCES}

ALMÉRIA, S., et al. Effects of crossbreed pregnancies on the abortion risk of Neospora caninum-infected dairy cows. Veterinary Parasitology, v. 26, n.4, p. 323-329, 2009. Available from: < https:// www.ncbi.nlm.nih.gov/pubmed/19464119>. Accessed: Oct. 11, 2017. doi: 10.1016/j.vetpar.2009.04.026

ANDERSON, M.L., et al. Neosporosis in cattle. Animal Reproduction Science, v.60-61, p.417-431, 2000. Available from: $<$ https://www.ncbi.nlm.nih.gov/pubmed/10844212>. Accessed: Oct. 20, 2017.

ASMARE, K., et al. Seroprevalence of Neospora caninum and associated risk factors in intensive or semi-intensively managed dairy and breeding cattle of Ethiopia. Veterinary Parasitology, v.193, p.85-94, 2013. Available from: $<$ https://www.ncbi.nlm.nih. gov/pubmed/23261087>. Accessed: Oct. 20, 2017. doi: 10.1016/j. vetpar.2012.11.025

BECK, R., et al. Seroprevalence and potential risk factors of Neospora caninum infection in dairy cattle in Croatia. Veterinarski Arhiv, v.80, n.2, p.163-171, 2010. Available from: $<$ http://hrcak srce.hr/index.php?show $=$ clanak\&id_clanak_jezik $=85436>$. Accessed: Oct. 20, 2017.

CAMILlO, G., et al. Detecção de anticorpos anto-Neospora caninum em amostras individuais e coletivas de leite de bovinos pela reação de imunofluorescência indireta. Pesquisa Veterinária Brasileira, v.31, n.6, pag. 482-486, 2011. Available from: $<$ http://www.scielo.br/scielo.php?script=sci_arttext\&pid=S0100736X2011000600004>. Accessed: Oct. 20, 2017. doi: 10.1590/ S0100-736X2011000600004

CÉZAR-CERQUEIRA, K.C., et al. All about neosporosis in Brazil. Revista Brasileira de Parasitologia Veterinária, v.26, n. 3, p.253-279, 2017. Available from: <http:/www.scielo.br/ scielo.php?pid=S1984-29612017005012101\&script=sci_arttext $>$. Accessed: Feb. 02, 2018. doi: 10.1590/S19884-29612017045.

COBERLLINI, L.G., et al. Herd-level risk factors for Neospora caninum soroprevalence in dairy farms in shouthern Brazil. Preventive Veterinary Medicine, v. 74, p. 130-141, 2006. Available from: $\quad<$ https://www.ncbi.nlm.nih.gov/pubmed/16343669>. Accessed: Oct. 9, 2017. doi: 10.1016/j.prevetmed.2005.11.004.

DUBEY J. P. Recent advances in Neospora and neosporosis Veterinary Parasitology, v.84, p.349-367, 1999. Available from: $<$ https://www.ncbi.nlm.nih.gov/pubmed/10456423>. Accessed: Oct. 9, 2017. doi: 10.1016/S0304-4017(99)00044-8.

DUBEY, J.P., et al. Epidemiology and control of neosporosis and Neospora caninum. Clinical Microbiology Reviews, v.20, n.2, p.323-367, 2007. Available from: <https://www.ncbi.nlm.nih. gov/pmc/articles/PMC1865591>. Accessed: Oct. 10, 2017. doi: 10.1128/CMR.00031-06.

DUBEY, J.P., et al. Gray wolf (Canis lúpus) is a natural definitive host for Neospora caninum. Veterinary Parasitology, v.181, n.2-
4, p.382-387, 2011. Available from: <https:www.ncbi.nlm.nih. gov/pubmed/21640485>. Accessed: Oct. 11, 2017. doi: 10.1016/j. vetpar.2011.05.018

DUBEY, J.P., et al. Newly recognized fatal protozoan disease of dogs. Journal of the American Veterinary Association, v.191, n. 9, p.1269-1285, 1988. Available from: <https:/www.nci.nlm.nih. gov/pubmed/3391851>. Accessed: Oct. 10, 2017.

DUBEY, J.P.; SCHARES, G. Diagnosis of bovine neosporosis. Veterinary Parasitology, v.140, n.1-2, p.1-34, 2006. Available from: <https://www.ncbi.nlm.nih.gov/pubmed/16730126>. Accessed: Oct. 11, 2017. doi: 10.1016/j.vetpar.2006.03.035.

DUBEY, J.P.; SCHARES, G. Neosporosis in animals: the last five years. Veterinary Parasitology, v.180, n.1-2, p.90108, 2011. Available from: <https://www.ncbi.nlm.nih.gov/ pubmed/21704458 $>$. Accessed: Oct. 10, 2017. doi: 10.1016/j. vetpar.2011.05.031.

FARIAS, N.A.; Neosporose. In: JUNIOR, J.S.; PEGORARO, L.M.C.; ZANELA, M.B.; Tecnologias para sistemas de produção de leite. Brasília, DF: Embrapa, 2016. Cap. 9, p.227-238.

FÁVERO, J.F., et al. Risk factors for Neospora caninum infection in dairy cattle and their possible cause-effect relation for disease. Microbial Pathogenesis, v.110, p.202-207, 2017. Available from: <https://www.sciencedirect.com/science/article/pii/ S0882401017303844>. Accessed: Feb. 02, 2018. doi: 10.1016/j. micpath.2017.06.42

FRANDOLOSO, R., et al. Prevalência de leucose enzoótica bovina, diarreia viral bovina, rinotraqueíte infecciosa bovina e neosporose bovina em 26 propriedades leiteiras da região Nordeste do Rio Grande do Sul. Ciência Animal Brasileira, v.9, n.4, p. 1102-1106, 2008. Available from: <https://www.revistas.ufg.br/ vet/article/view/1398>. Accessed: Oct. 11, 2017.

FRANKENA, K.; GRAAT, E.A.M. Multivariate analysis: logistic regression. In: NOORDHUIZEN, J.P.T.M.; FRANKENA, K.; VAN DER HOOFD, C.M. et al. Application of quantitative methods in veterinary epidemiology. Wageningen: Wageningen Pers, p.135-178, 1997

GONDIM, L.F.P., et al. Coyotes (Canis latrans) are definitive hosts of Neospora caninum. International Journal of Parasitology, v.34, p.159-161, 2004. Available from: <https://www.ncbi.nlm.nih. gov/pubmed/15037103>. Accessed: Oct. 11, 2017. doi: 10.1016/j. ijpara.2004.01.001.

GUIMARÃES JUNIOR, J.S., et al. Prevalence of Neospora caninum antibodies and factors associated with their presence in dairy cattle of north of Paraná state, Brazil. Veterinary Parasitology, v. 124, p. 1-8, 2004. Available from: <https:www. ncbi.nlm.nih.gov/pubmed/15350656>. Accessed: Oct. 11, 2017 doi: 10.1016/j.vetpar.2004.07.002

HADDAD J.P., et al. A review Neospora caninum in dairy and beef cattle - a Canadian perspective. Canadian Veterinary Journal, v. 46, p. 230-243, 2005. Available from: <https://www.ncbi.nlm. nih.gov/pubmed/15884645>. Accessed: Feb.02, 2018.

HEIN, H.E., et al. Neosporose bovina: avaliação da transmissão vertical e fração atribuível de aborto em uma população de bovinos no Estado do Rio Grande do Sul. Pesquisa Veterinária Brasileira, v.32, n.5, p. 396-400, 2012. Available from: <http:// 
www.scielo.br/scielo.php?pid=S0100736X2012000500006\&scrip $\mathrm{t}=$ sci_abstract\&tlng=pt $>$. Accessed: Oct. 20, 2017. doi: 10.1590/ S0100-736X2012000500006.

IBGE. Produtos de origem animal, por tipo de produto. Available from: <https://sidra.ibge.gov.br/tabela/74\#resultado $>$. Accessed: Nov. 24, 2017.

JUSTO, R.V., et al. Seroepidemiological inquiry on bovine neosporis in northen Mato Grosso state, Brazil. Semina: Ciências Agrárias, Londrina, v.34, n.6, p.3897-3902, 2013. Available from: <http://www.uel.br/revistas/uel/index.php/ semagrarias/article/view/14138>. Accessed: Oct. 20, 2017. doi: 10.5433/1679-0359.2013v3an6Supl2p3897.

KLAUCK, V. et al. Relation between Neospora caninum and abortion in dairy cows: Risk factors and pathogenesis of disease. Microbial Pathogenesis, v.92, p.46-49, 2016. Available from: $<$ https://www.sciencedirect.com/science/article/pii/ S088240101530200X?via\%3Dihub>. Accessed: Mar. 03, 2018. doi: 10.1016/j.micpath.2015.12.015.

MARTINEZ, B.A., et al. Can hierarchical modeling improve our understanding of bovine abortion due Neospora caninum infection? Veterinary Parasitology, v. 237, p. 77-82, 2017. Available from: $<$ https://www.ncbi.nlm.nih.gov/pubmed/28259557>. Accessed: Feb. 02, 2018. doi: 10.1016/j.vetpar.2017.02.016.

MARTINS, A.A., et al. Frequency and risk factors for neosporosis in dairy farms of Umuarama, Pr, Brazil. Arquivos de Ciências Veterinárias e Zoologia, v.15, n.2, p.137-142, 2012. Available from: <http://revistas.unipar.br/index.php/ veterinaria/article/view/4217/2626>. Accessed: Oct. 20, 2017.

MOORE, D.P. Neosporosis in South America. Veterinary Parasitology, v.127, p.87-97, 2005. Available from: $<$ https://www. ncbi.nlm.nih.gov/pubmed/15631900>. Accessed: Oct. 11, 2017. doi: 10.1016/j.vetpar.2004.10.001.

MOURA, A. B., et al. Anticuerpos séricos contra Neospora caninum en rebaños lecheros de la ciudad de Lages, Estado de Santa Catarina, Brasil. Archivos de Medicina Veterinaria, v. 44, p. 117-122, 2012. Available from: $<$ http://www.scielo.cl/scielo.php?script $=$ sci arttext\&pid=S0301-732X2012000200004>. Accessed: Oct. 20, 2017. doi: 10.4067/S0301-732X2012000200004.

NASCIMENTO E.E., et al. Anti-Neospora caninum antibody detection and vertical transmission rate in pregnant zebu beef cows (Bos indicus): Neospora caninum in pregnant beef cows
(Bos indicus). Comparative Immunology, Microbiology and Infectious Diseases, v.37, n.4, p. 267-260, 2014. Available from: $<$ https:/www.ncbi.nlm.nih.gov/pubmed/25193073>. Accessed: Feb. 02, 2018. doi: 10.1016/j.cimid.2014.08.002.

OGAWA, L., et al. Ocurrence of antibodies to Neospora caninum and Toxoplasma gondii in dairy cattle from the northern region of Paraná Satate, Brazil. Arquivo Brasileiro de Medicina Veterinária e Zootecnia, v.57, n.3, p.312-316, 2005. Available from: <http://www.scielo.br/scielo.php?script=sci_arttext\&pid $=\mathrm{S} 0102-09352005000300006>$. Accessed: Oct. 11, 2017. doi: 10.1590/S0102-09352005000300006.

PABÓN, M., et al. Chronic Neospora caninum infection and repeat abortion in dairy cows: A 3-year study. Veterinary Parasitology, n.147, p. 40-46, 2007. Available from: <https://www.ncbi.nlm.nih. gov/pubmed/17467905>. Accessed: Oct. 11, 2017. doi: 10.1016/j. vetpar.2007.03.017

PETRIE, A.; WATSON, P. Estatística em ciência animal e veterinária. 2 th ed. São Paulo: Roca, 2009. 236 p.

RAGOZO, A.M.A., et al. Ocorrência de anticorpos ANTINeosporacaninum em soros bovinos procedentes de seis estados brasileiros. Revista Brasileira de Parasitologia Veterinária, v.12, n.1, p. 33-37, 2003. Available from: <http://www.rbpv.ufrrj.br/ documentos/1212003/c12133_37.pdf>. Accessed: Oct. 20, 2017.

REICHEL, M.P., etal. What is the global economicimpact of Neospora caninum in cattle - The billion dollar question. International Journal for Parasitology, v.43, p. 133-142, 2013. Available from: $<$ https://www.ncbi.nlm.nih.gov/pubmed/23246675>. Accessed: Oct. 11, 2017. doi: 10.1016/j.ijpara.2012.10.022.

SAMPAIO, I.B.M. Estatística aplicada à experimentação animal. Belo Horizonte: FEPMVZ, 1998. 221p.

SERGEANT, E. S. G. Epitools epidemiological calculators. AusVet Animal Health Services and Australian Biosecurity Cooperative Research Centre for Emerging Infectious Disease. 2014. Available from: $<$ http:// epitools.ausvet.com.au>. Accessed: May 22, 2016.

VOGEL, F.S.F.V., et al. Antibodies to Neospora caninum in cattle, sheep and water in Rio Grande do Sul state, Brazil. Ciência Rural, v.36, n.6, p. 1948-1951, 2006. Available from: $<$ http://www.scielo.br/scielo.php? script=sci_arttext\&pid $=$ S0103-84782006000600048 $>$. Accessed: Oct. 20, 2017. doi: 10.1590/S0103-84782006000600048. 